\title{
Isolation and Identification of Organisms and Production of Single Cell Protein by Using Natural Gas
}

\author{
Deepika Shete and Savanta Raut* \\ Department of Microbiology, Bhavan's College Andheri[W] Mumbai-400058, India \\ *Corresponding author
}

\section{A B S T R A C T}

\section{Keywords}

Natural Gas, Isolate, Single Cell Protein (SCP), SDS

Article Info

Accepted:

15 November 2018

Available Online:

10 December 2018

\begin{abstract}
Natural gas is mainly released from wetlands, rice fields, enteric fermentation in animals and landfills etc. It also has impact on environment as it leads to greenhouse effect. In this research natural gas is used for isolation of natural gas utilizing organisms from rice paddy field and Garden soil. These isolates were further screened for Single Cell Production (SCP) by using natural gas as a sole source of carbon.6 isolates out of 11 isolates were used for further studied. Isolate No. 9 and No. 10 i.e. Candida Lusitania showed $40 \%$ and $30 \%$ of protein respectively with $1 \%$ and $13 \%$ Nucleic acid content respectively. Single Cell Protein (SCP) produced from the isolates were subjected for Sodium Dodecyl Sulphate (SDS) PAGE analysis which showed 40kDa band size.
\end{abstract}

\section{Introduction}

SCP refer as the dried microbial cell or total protein extracted from pure microbial cell culture (algae, bacteria. Filamentous fungi, yeast) which can be used as food supplement to human (Food grade) or animals (Feed grade) (A. R. Srividya, 2014).Despite of low solubility, flammability, and impurity in natural sources, methane is a good candidate for single cell protein (SCP) production for its nontoxicity, selectivity and volatility ( Nalage, 2016). Single Cell Protein (SCP) is one of the most important steps for this goal and it is an alternative and an innovative way to successfully solve the global food problem (K. $\mathrm{Xu}$, Y. T. 2013).
Several investigators have shown the ability of methane for being utilized by relevant organisms for protein production from cheap and vast carbon sources; i.e. natural gas. Hence, natural gas as a carbon source could be placed among other potential substrates which results in saving world from protein scarcity. Since methane has formed the largest part of natural gas [85 to $90(\mathrm{v} / \mathrm{v}) \%$ ], SCP production from this substrate could be economically reasonable due to accessibility and cheapness of natural gas resources (Nalage, 2016).

\section{Advantage of Natural gas over other substrates to produce SCPs}

The natural gas methane at first sight appears to be an attractive substrate for SCPs because 
it is easily available and relatively inexpensive.

It is pure.

It requires less quantities as compared to other substrates.

Natural gas is a mixture of various hydrocarbons molecules and methane is a main component. Among all greenhouse gases methane account for about $15-20 \%$ of total global warming effect. The sources of methane gas emission contributing about 50\% of total methane emission includes wetlands, rice fields, enteric fermentation in animals, termites and landfills etc. The aerobic organisms may contribute up to $10-20 \%$ to the total methane destruction. So, isolating efficient methane degrading bacteria from natural habitats may present a near long term advantage in solving global warming problem. (WulfCrueger 1990).

Natural gas is one of such fuel available in large quantities with very attractive prices in many parts of the world. Natural gas consumption is forecasted to be doubled between 2001 and 2025, in most of the developing nation. Natural gas (NG) is a potential alternative to conventional liquid fuels (i.e. gasoline and diesel) for use in automotive engines. Natural gas is a mixture of various hydrocarbon molecules (Kakaee, 2014).

Global warming is an environmental issue that deals with the potential for global climate changes due the increased levels of atmospheric greenhouse gases. The main component of natural gas, methane, is itself a potent greenhouse gas (Liang, 2012). Among all greenhouse gases methane account for about $15-20 \%$ of total global warming effect. The sources of methane gas emission contributing about $50 \%$ of total methane emission includes wetlands, rice fields, enteric fermentation in animals, termites and landfills etc. The only known biological sink for atmospheric methane is its oxidation in aerobic soils by "methanotrophic (=methylotrophic) bacteria", this may contribute up to $10-20 \%$ to the total methane destruction. So, isolating efficient methane degrading bacteria from natural habitats may present a near long term advantage in solving global warming problem (Yoshioka, 2015).

\section{Natural gas composition}

The composition of natural gas varies depending on many factors like the origin, location of deposit and geological structure. Natural gas mainly consists of saturated aliphatic hydrocarbons like methane. Components such as carbon dioxide, hydrogen sulphide, nitrogen and helium constitute an insignificant proportion of natural gas composition. The typical composition of natural gas in percentage is illustrated in Figure 1. Therefore, natural gas does not describe a single type of fuel or a narrow range of characteristics. (Liang, 2012)

\section{Natural gas uses}

Natural gas has several applications commercially in homes, industries and the transportation as follows (Liang, 2012):

1. Residential use: Natural gas is one of the cheapest forms of energy available to residential consumers; it is even cheaper than electricity as a source of energy. Natural gas is used for heating and cooking.

2. COMMERCIAL USES: The main commercial uses of natural gas include space heating, water heating and cooling. See Table 1 for the exact percentage allocated to each type of use. Natural gas is an efficient and economical fuel for commercial buildings. 
3. INDUSTRIAL USE: Natural gas helps provide base ingredients for products like plastic, fertilizer, anti-freeze and fabrics. Natural gas is used primarily in the metal, chemical, petroleum refining, stone, clay and glass, pulp and paper, plastic and food-processing industries.

4. TRANSPORTATION SECTOR: As per natural gas vehicle coalition estimates there are 120,000 Natural Gas Vehicles (NGV) in USA and more than 8.7 million NGV worldwide. There are about 1,100 natural gas fuelling stations in USA alone.

\section{Materials and Methods}

\section{Soil sample}

Soil were collected from two locations. Rice field soil from Pune and Bhavan's College Campus Soil. The soil was collected and processed on same day except for Rice field soil from Pune, which was store at $5^{0} \mathrm{C}$ before use.

1:10 and 1:100 dilution were made and spreaded on Bushnell \& Hass agar plate which kept in the close container with Natural gas as a sole source of carbon fro 48-72hrs.

Isolation was done on Nutrient agar followed by Bushnell and Hass agar. Purity was checked by microscopic examination.

Production of single cell protein from natural gas

The isolated organisms were grown in Bushnell \& Hass Broth at $\mathrm{pH} 5.5$ as test and for control in Sabouraud broth at $\mathrm{pH} 5.5$ with optical Density was adjusted at $540 \mathrm{~nm}$ with 0.7 reading to get density up to $1 \times 10^{5} \mathrm{cells} / \mathrm{ml}$ by plating on Sabourad plates for $48 \mathrm{hrs}$. The same inoculum with $1 \times 10^{4} \mathrm{cells} / \mathrm{ml}$ was added to $50 \mathrm{ml}$ of Bushnell \& Hass Broth (Test) and Sabouraud (Control) and it was incubated at room temperature on shaker for $48 \mathrm{hrs}$.

Preparation of cell free extract and Protein Estimation: (Jhala, 2014)

Cell free extract was prepared by centrifugation of cell biomass for 15 mins at $10,000 \mathrm{rpm}$ wash by suspending in $0.1 \mathrm{M}$ potassium phosphate buffer ( $\mathrm{pH}$ 5.4), the washed cell was suspended in the same buffer, homogenize and disruption by ultrasonic treatment of $50 \mathrm{~Hz} 5$ mins. The suspension then centrifuged at 10,000 rpm for 30 minutes and the resulting supernatant and pellet was used as crude extract.

\section{Estimation of protein content of SCP}

Protein quantity was measured using Robinson \& Hogden method for bacterial and yeast isolates (WulfCrueger, A. C. 1990). The protein of yeast isolates was determined by the Bradford method which is sensitive method for protein estimation. Using standard chart graphed for known protein concentrations, quantity of each protein was calculated.

\section{Estimation of DNA from SCP}

Nucleic acid as measured using Diphenylamine method for bacterial and yeast isolates (J.R. Norris, D. R. 1971). Using standard chart graphed for known DNA concentrations, quantity of each DNA was calculated.

\section{Natural Gas utilizing activity of isolate (Yogeshvari, 2016)}

Suspected isolates were tested for utilization of natural gas as sole source of carbon in tubes containing Bushnell \& Hass broth + natural gas (head space of the tube) for confirmation. Growth and survival of isolates was measured 
by performing Robinson \& Hogden method for protein estimation.

\section{SDS PAGE Analysis of SCP}

Sodium dodecyl sulphate polyacrylamide gel electrophoresis (SDS-PAGE) is a technique for separating proteins based on their ability to move within an electrical current, which is a function of the length of their polypeptide chains or of their molecular weight.An SDS PAGE during stacking and increased to $30 \mathrm{~mA}$ when the sample was entering the running gel. After the electrophoresis was complete and plates were removed, the gel should be kept in the fixative for about 60 minutes. Staining was performed with the Coomassie blue R-250dye overnight. Then the gel was distained using solution 1. After destining it should be preserved in $10 \%$ glycerol.

\section{Identification of isolates by Vitek Complete Automated System}

Yeast isolate was identified using Vitek 2 Complete automated system.

\section{Results and Discussion}

\section{Isolation of Natural Gas Utilising organisms from Soil}

The soil suspension was spread on Bushnell \& Hass agar which gave multiple pigmented and colourless colonies. There were totally 11 colonies obtained from Bhavan's Campus Garden Soil and Rice Field (Pune). But Jhala Yogeshvari (2015) isolated 74 colonies from rhizospheric soil of rice on Nitrate mineral salt medium/ammonium mineral salt medium with $1 \%$ methane as a sole source of carbon. The colonies obtained on Bushnell \& Hass agar was preliminary isolated again on the Bushnell \& Hass agar in presence of Natural gas as a sole source of carbon in a Close chamber (Desiccator). The morphology of the isolates obtained was studied using microscopic observation which showed some grampositive cocci and some gram-positive rods and yeast colonies.

The obtained isolate was further processed for production of Single Cell Protein (SCP) performing viable count to add same amount of bacterial/yeast concentration in the Nutrient agar (Bacteria) and Sabouraud agar (yeast) which was adjusted to $1 \times 104$ cells $/ \mathrm{ml}$ at 540nm. (MetteSvenning et al., 2003) After $48 \mathrm{hrs}$ of incubation the centrifugation was done to obtained biomass. The differences in the maximum yield, while using the different inoculum sizes may lie in the fact that different microorganisms, substrates and fermentation techniques were employed. (Fakhar-un-NisaYunus, 2015) The biomass was further processed for protein and DNA estimation.

\section{Protein content}

Firstly, the protein estimation of whole biomass was done by Robinson \& Hogden method in which two sets were run. $1^{\text {st }}$ set contains isolates grown in Bushnell \& Hass broth with Natural Gas which is used as test and in second set the isolates were allowing to grow in control medium i.e. Nutrient broth for bacteria and Sabouraud broth for yeast. From figure 3 it was observed that by comparing test and control medium isolate number 9 and 8 $\& 10$ showed maximum amount of protein in Bushnell \& Hass broth containing Natural gas as sole source of carbon which is $40 \%$ and $30 \%$ respectively.

Protein estimation of only yeast isolate was done by Bradford assay which detect partially soluble and insoluble protein concentration and has high sensitivity range. In this maximum amount of protein was observed in isolate 7,8 and 9 which is $25.86 \%, 37.6 \%$ and $73.2 \%$ respectively. The isolate 9 showed maximum amount of protein i.e. $73.2 \%$. 
As the protein estimation of the obtained isolates was done by using Robinson \& Hogden method and Bradford's method. It was observed that the protein concentration calculated from Robinson showed $40 \%$ protein in isolate 9 while in Bradford method it showed $73.2 \%$. This is because Bradford method is very sensitive method for protein determination with minimum sample volume upto $1 \mu \mathrm{l}$ and it can detect both soluble protein which is available in supernatant and insoluble protein from pellets.

\section{DNA content of SCP}

Nucleic acid (DNA) was determined by Diphenylamine (DPA) method of the isolates. Because when SCP is produced for human consumption, high nucleic acid content is not favourable as ingestion of purine compounds derived from RNA breakdown increases uric acid concentrations in plasma, which can cause gout and kidney stones (Anneli Ritala, 2016). Figure 5 and 6 showed that maximum DNA was produced by isolate 6 . If we compare high protein producing isolate with their nucleic acid production i.e. isolate 9 and 10 it was observed that isolate 9 showed $1 \%$ of DNA and isolate 10 showed $13 \%$ of DNA. From above observation isolate number 9 is suitable for protein production with low nucleic acid content. Because for human consumption, the nucleic acid content of the SCP should be reduced to below 9\%. If any substantial amount of SCP is used in the diet. [Shay, 1981 (European Patent Grant)]

\section{Natural gas utilisation activity of isolate}

Natural gas utilisation activity was dome by adjusting parameter i.e. concentration of natural gas for 5 secs, 10 secs and 30 secs for isolate number 9 and 10. From which isolate 10 showed protein concentration to be $10 \%$, $16.6 \%$ and $30 \%$. Hence fixed amount of Natural gas can be used to increase the protein production. The sterility should be maintained throughout the SCP production and fermentation process to get pure protein without any toxic contamination.

\section{Characterisation of single cell protein by SDS PAGE}

Based on SDS PAGE result supernatant of yeast isolate 6 showed 4 bands while 5 bands in pellet of same isolate. Isolate 7 showed 4 bands in both supernatant and pellet. Isolate 8 showed 6 bands in supernatant but the pellet bands were not visible. Pellet of isolate 8 was showing only 1 band. Isolate 9 showed 6 bands in supernatant. All the other supernatant and pellets of the remaining isolates showed similar band size near $66 \mathrm{kDa}, 40 \mathrm{kDa}$ and $20 \mathrm{kDa}$. As the concentration of protein was very less hence $4 \mu \mathrm{g} / \mathrm{ml}$ Marker was inserted

The SDS PAGE was run to identify the protein based on their molecular weight of the protein. From Figure 7, 8 and 9 which showed similar type of band in almost all the supernatant and pellet which was near 40kDa. Isolates showing similar of $\sim 40 \mathrm{kDa}$ indicating that these isolates may have capacity to utilise natural gas as sole source of carbon (Richard, 2009). The enzyme responsible of natural gas utilisation is still unknown. But in Richard 2009 article showed 66kDa for Thauera butanivorans by running native PAGE electrophoresis.

\section{Identification of isolates}

Isolation, identification of methanotrophic are high relevance because of the special emphasis on their role in methane emission to the atmosphere, in bioremediation and in industry related to single cell protein production based on natural gas. (Mette Svenning, 2003) Among the isolate obtained in Jhala Yogeshvari (2015) research showed that Rhizobium sp, B. megaterium, 
$B$. aerius and $B$. subtilis was proved to be efficient methane degrader. The identification of 6 yeast isolate was done from which 4 isolates i.e. 1, 3, 4 and 5 was found to be Candida Lusitania and isolate 2 and 6 was found to be Bacillus megaterium. The isolated culture may be the same, but strain might differ. The identification was done by Vitek 2 Compact automated system.

Isolation of organisms from Bhavan's College Campus soil and Rice field was done from which 11 isolates were obtained. 6 yeast isolates out of 11 isolates was further used for
Single Cell Protein (SCP) production. Isolate 9 i.e. Candida Lusitania was able to produce maximum amount of protein i.e. $73.2 \%$ by Bradford assay with low nucleic acid content i.e. $1 \%$ which is very important for production of Single Cell Protein (SCP) for human consumption. The SDS PAGE analysis showed $\sim 40 \mathrm{kDa}$ band in the isolates. Hence isolate 9 i.e. Candida Lusitania can be subjected to the known concentration of Natural Gas to yield high concentration of protein with low nucleic acid content for human consumption and animal feed.

Table.1 Composition of crude single cell protein (percent)

\begin{tabular}{|c|c|c|c|c|c|}
\hline & Alkane yeast & $\begin{array}{c}\text { Methanol } \\
\text { bacterium }\end{array}$ & $\begin{array}{c}\text { Protein } \\
\text { isolate }\end{array}$ & Fungus & Alga \\
\hline Raw Protein & 60.0 & 83 & 80 & 42 & 70 \\
\hline Fat & 9.0 & 7.4 & $8-10$ & 13 & 5 \\
\hline Nucleic Acid & 5.0 & 15 & $1-2$ & 9.7 & 4 \\
\hline Mineral Salts & 6.0 & 8.6 & $8-12$ & 6.6 & 7 \\
\hline Amino Acids & 54 & 65 & - & - & - \\
\hline Moisture & 4.5 & 2.8 & 4.0 & 13.0 & 6 \\
\hline
\end{tabular}

Ref: Wulf Crueger, A. C. (1990). Chapter 16: Single-Cell Protein. In T. D. Brock, Biotechnology: A Textbook of Industrial Microbiology (pp. 306-325). Sunderland: Sinauer.

Fig.1 Typical Natural gas composition by volume

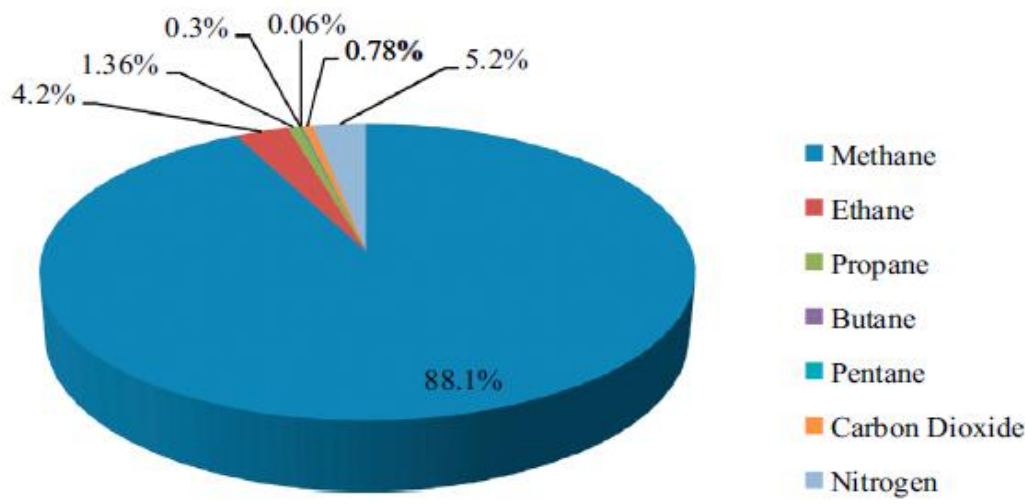




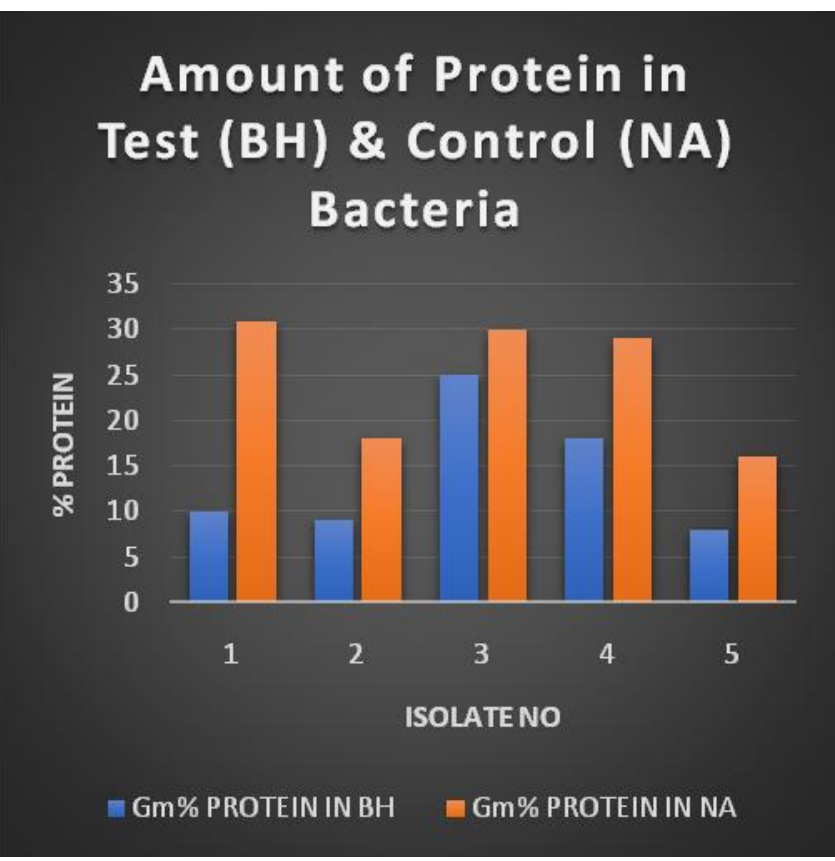

Fig.2 Graphical Representation of Total Amount of protein of bacterial isolate in Test

(Bushnell \& Hass medium) \& Control

(Nutrient broth medium)

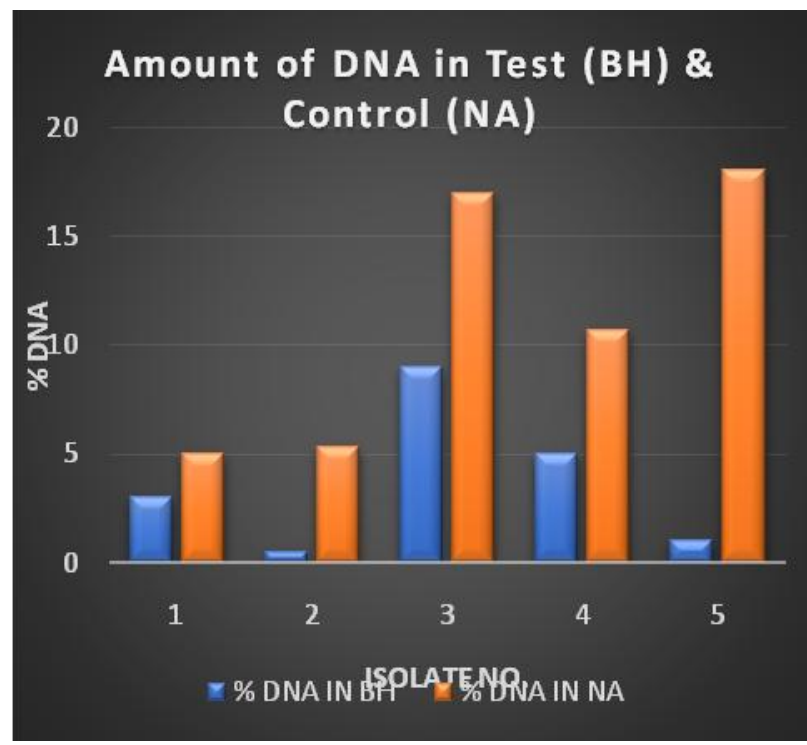

Fig.4 Graphical Representation of Total Amount of DNA of yeast isolate in Test $(\mathrm{BH}$ medium) \& Control (NA medium)

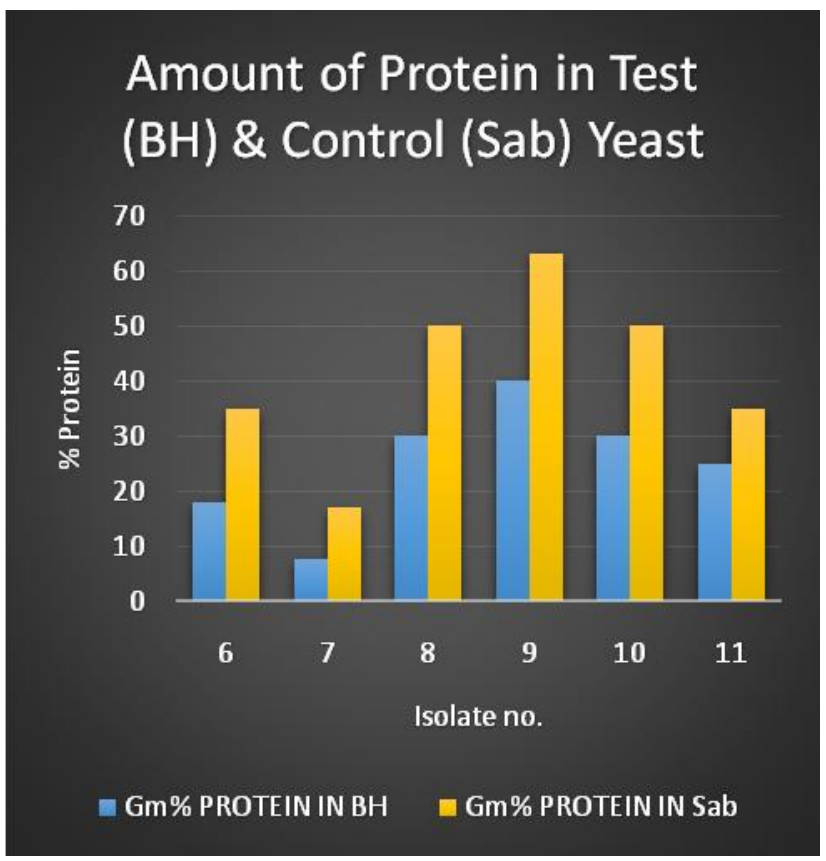

Fig. 3: Graphical Representation of Total Amount of protein of yeast in isolate Test (Bushnell \& Hass medium) \& Control (Sabourad medium)

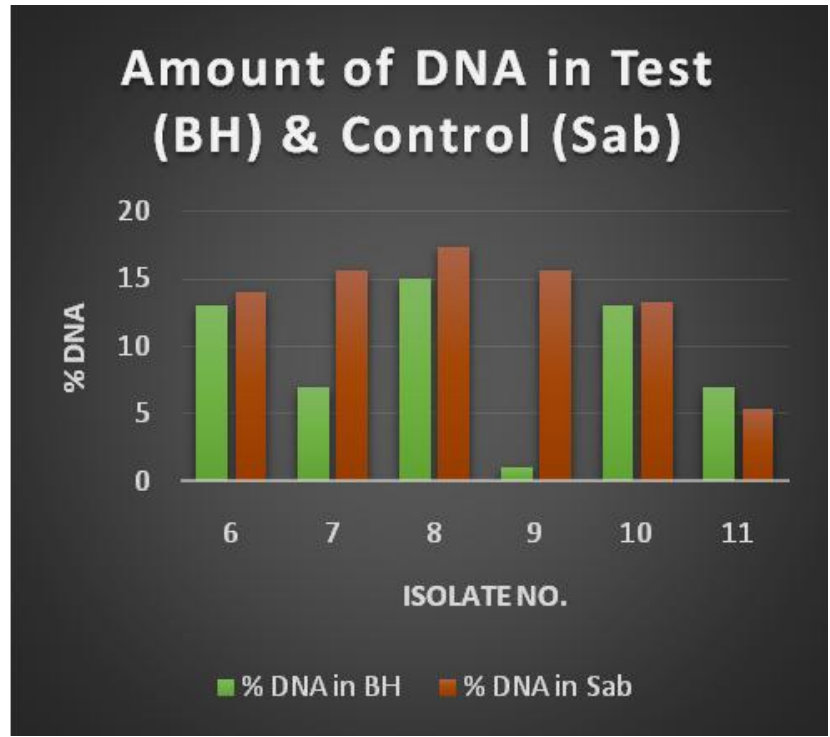

Fig.5 Graphical Representation of Total Amount of DNA of yeast isolate in Test Amount of DNA of yeast isolate in Test $(\mathrm{BH}$ medium) \& Control (Sab medium) 


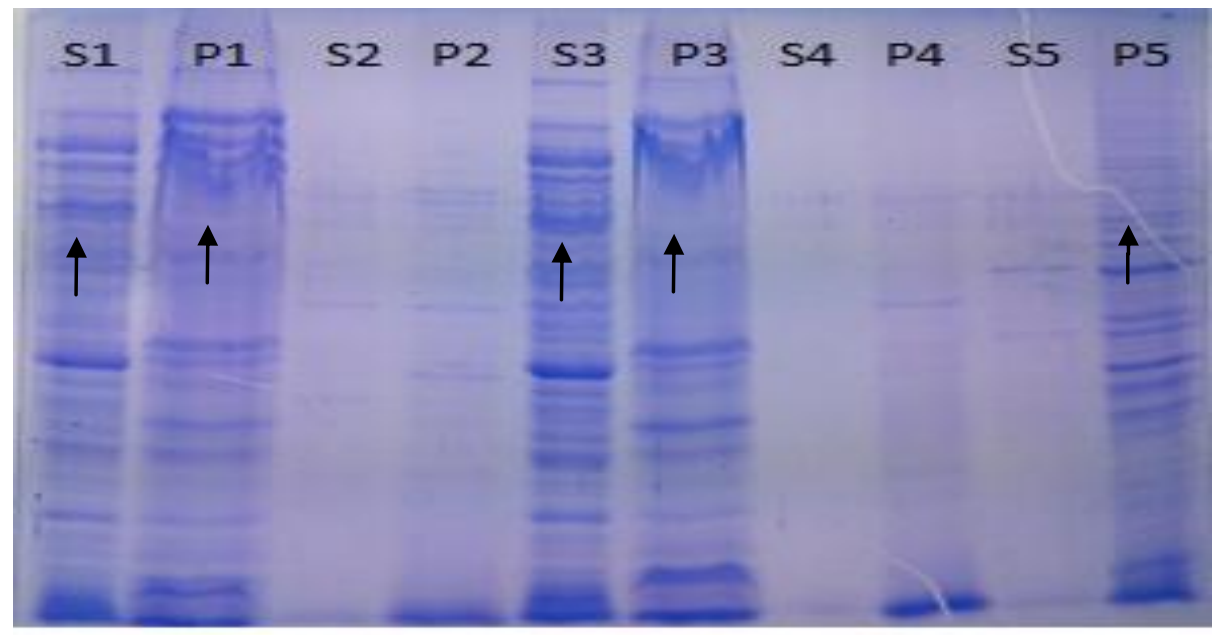

Fig.7 SDS after distaining for Suspension (s) and pellets (P) of yeast isolate 1 to 5

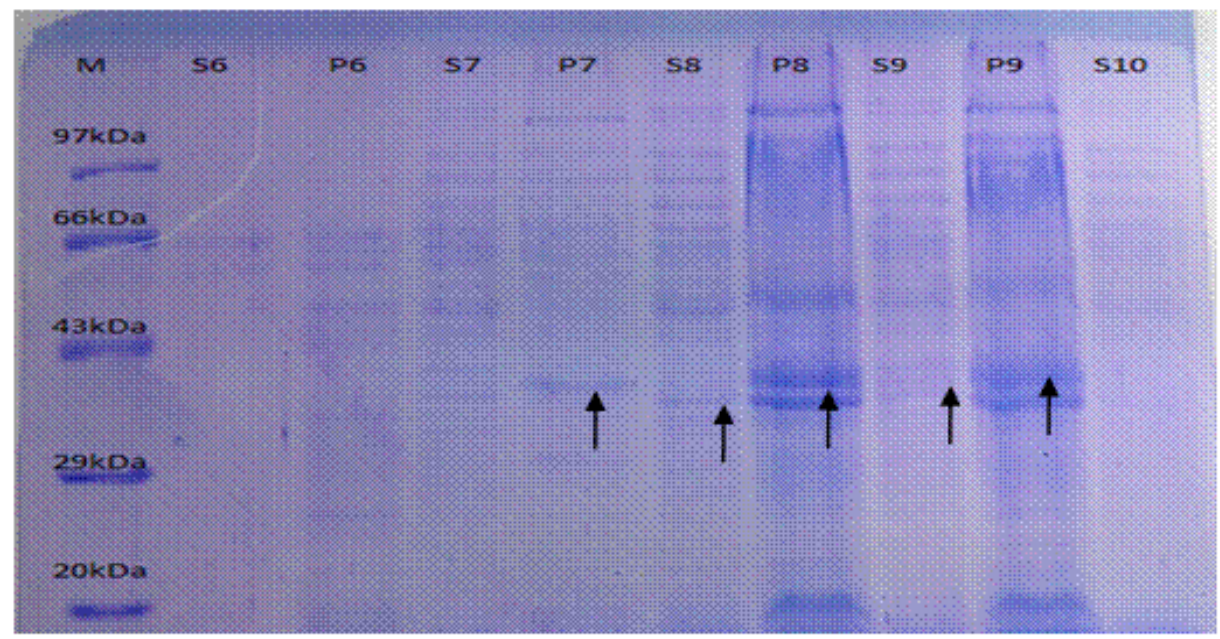

Fig.8 SDS after distaining for Supernatant (S) and pellets (P) of yeast from isolate 6 to 10

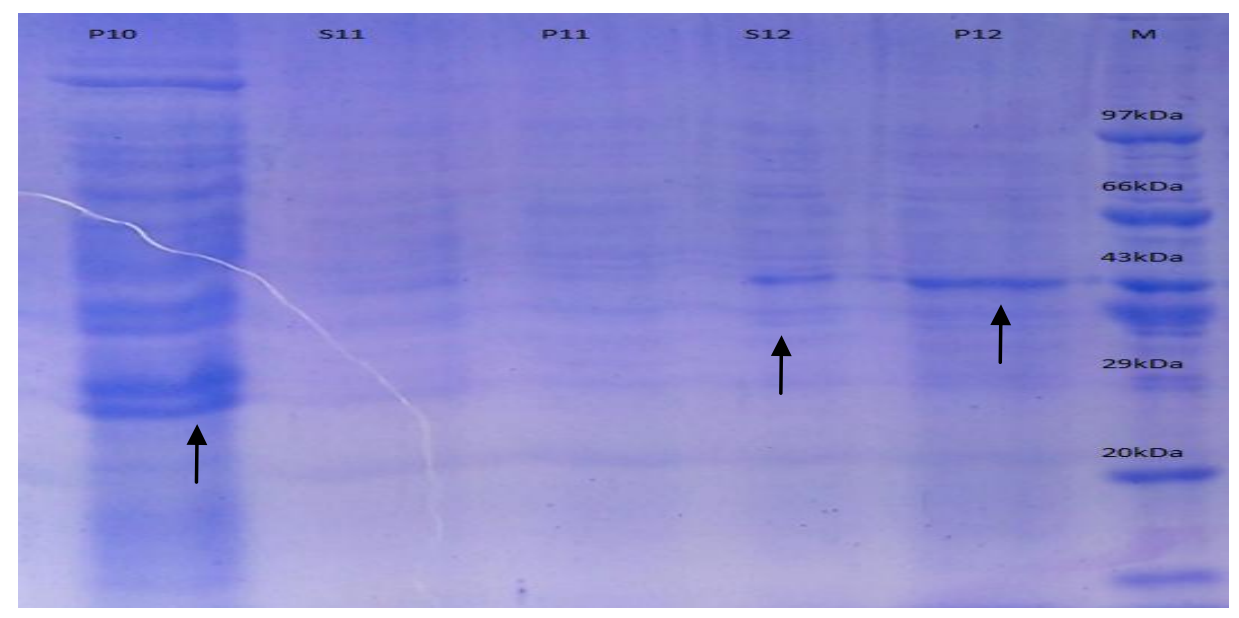

Fig.9 SDS after distaining for Supernatant (s) and pellets (p) of yeast from isolate 11 and 12 
In conclusion, landfill gas is produced through microbial anaerobic degradation of organic waste and is mainly composed of methane and carbon dioxide, typically in the concentrations of 55-60\% methane and 40-45 $\%$ carbon dioxide. Methane is a greenhouse gas up to 25 times more potent than carbon dioxide, as it is more effective at absorbing infrared radiation. Landfills are estimated to contribute with up to $5 \%$ of overall global greenhouse gas emissions today or about $18 \%$ of global $\mathrm{CH} 4$ emissions. (Alexandra Kjeld, 2014) The Rice field and Bhavan's Campus Garden was selected. From which overall 20 isolates were found mainly bacteria and yeast.

For production of single cell protein (SCP) from natural gas, the methane utilising microorganisms chose due to their higher growth rate characteristics. (Fatemeh Yazdian, 2005) These isolated organisms were further used for Single Cell Protein (SCP) production as natural gas as a substrate for protein production. Single cell protein has various benefit over animal and plant proteins in that its requirement for growth are neither seasonal nor climatic dependent therefore it is produced around the year (Kelechi M. Ukaegbu-Obi, 2016)

Among all the isolates isolate 9 and 10 i.e. Candida Lusitania produced maximum concentration of protein with less nucleic acid content which can be further used for animal feed and human consumption. Removal of Nucleic acids from single cell producing organisms is important. Several methods have been proposed to reduce nucleic acid levels in SCP. These methods involve chemical and enzymatic treatments. Each has disadvantages both in terms of cost and potential nutritional concern. In 1977, the extraction of nucleic acid by acidified alcohol, salt, acid and alkalis has been proposed (Nasseri, 2011).

The identification of genes responsible for natural gas utilisation can be done from the above isolates for maximum protein production. It has practical in diverse field such as food processing, Nutraceuticals, fisheries, etc. Microbes have a shorter generation time, allow easy transformation, utilize many substrates, have no requirements for arable land or any particular season to grow and have the possibility of continuous production in many parts of the world (Fakhar-un-NisaYunus, 2015).

We fervently hope that this study will contribute in a small yet significant way to the production of single cell protein from natural gas and research in the field of microbiology.

\section{References}

Nasseri, A. T. S. R.-A. (2011). Single Cell Protein: Production and Process. American Journal of Food Technology, 6(2), 103-116.

Alexandra Kjeld, A. R. (2014). Microbial Methane Oxidation at the Fiflholt landfill in Iceland. Ritryndarvísindagreinar 31-36.

Nalage, G. K. (2016). Single Cell Proteins. Encyclopedia of Food \& health, 792796.

Fakhar-un-NisaYunus, M. N. (2015). Singlecell protein production through microbial conversion of lignocellulosic residue (wheat bran) for animal feed. Institute of Brewing \& Distilling, 121, 553-557.

GourSuman, M. N. (2015). Single Cell Protein Production: A Review. International Journal of Current Microbiology and Applied Science, 4(9), 251-262.

Hideyoshi Y. H. (2015). Methane production potential of subsurface microbes in Pleistocene sediments from a natural gas field of the dissolved-in-water type, central Japan. Chemical Geology, 419, 92-101.

Hogden. (1940). The biuret reaction for the 
determination of serum protein. 724731.

J.R. Norris， D. R. (1971). Chapter VI Separation and Purification of Proteins. In Methods in Microbiology (Vol. 5B, pp. 244-249). ACADEMIC PRESS London and New York.

Jhala Y K, V. R. (2016). Rapid Methods for Isolation and Screening of Methane Degrading Bacteria. Journal of Bioremediation \& Biodegradation, 7(1), 2155-6199.

Kakaee A. H., A. n. (2014). The influence of fuel composition on the combustion and emission characteristics of natural gas fuelled engines. Renewable and Sustainable Energy Reviews, 38, 6478.

Laing, N. D. (2011). Sodium dodecyl sulphate polyacrylamide gel electrophoresis (SDS-PAGE) of crude extracted insecticidal crystal proteins of Bacillus thuringiensis and Brevibacillus laterosporus. African Journal of Biotechnology, 10(66), 15094-15099,.

Mette M. Svenning, I. W. (2003). Isolation of methane oxidising bacteria from soil by use of a soil substrate membrane system. FEMS Microbiology Ecology, 44, 347-354.

Richard B. Cooley, 1. P. (2009). Growth of a non-methanotroph on natural gas: ignoring the obvious to focus on the obscure. Environmental Microbiology Reports, 1(5), 408-413.

Ritala A, S. T. (2017). Single Cell ProteinState-of-the-Art, Industrial Landscape and Patents 2001-2016. Frontiers in Microbiology, 1-18.

Shay. (1981). European Patent Application. European Patent Office, 1-32.

Surva Roy, V. K. (2012). A Practical Approach on SDS PAGE for Separation of Protein. International Journal of Science and Research (IJSR), 3`(8), 955-960.

Ukaegbu-Obi, K. M. (2016). Single Cell Protein: A Resort to Global Protein Challenge and Waste Management. Journal of Microbiology \& Microbial Technology, 1(1), 1-5.

Wulf Crueger, A. C. (1990). Chapter 16: Single-Cell Protein. In T. D. Brock, Biotechnology: A Textbook of Industrial Microbiology (pp. 306-325). Sunderland: Sinauer.

\section{How to cite this article:}

DeepikaShete and Savanta Raut. 2018. Isolation and Identification of Organisms and Production of Single Cell Protein by Using Natural Gas. Int.J.Curr.Microbiol.App.Sci. 7(12): 1778-1787. doi: https://doi.org/10.20546/ijcmas.2018.712.207 